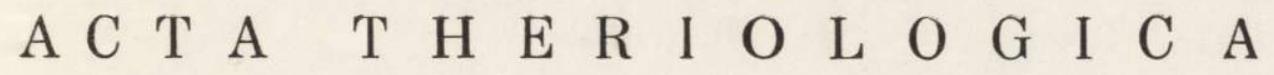

VOL. XVI, 26: $413-422$.

BIAŁOWIEŻA

December, 1971

BISONIANA XLI

Małgorzata K R A S I Ń S K A

\section{Hybridisation of European Bison with Domestic Cattle. Part VI}

[With 3 Tables \& 1 Fig.]

The study presents results obtained in experimental cross-breeding of European bison and domestic cattle during the period from 1966-1970. During this period 17 hybrids of generation $\mathrm{B}_{1}(3 / 4$ domestic cattle $)$ and 9 individuals of $\mathrm{B}_{2}(7 / 8$ domestic cattle) were obtained. In all from the start of the experiment a total of 11 individuals of generation $F_{1}, 25$ of $B_{1}$ and 9 of $B_{2}$ were obtained. Length of gestation in $F_{1}$ cows was on an average 275.6 days, but in generation $B_{1}-277.2$ days, that is, a period similar to that typical of cattle. Not all $B_{1}$ cows produced young. The seasonal character of reproduction observed in the first generation of hybrids disappears in generation $\mathrm{B}_{1}$. Oestrus occur at different times of the year - the first at an average age of 13.2 months. Young bulls begin to cover females during this period. Sexual maturation occurs in $B_{1}$ hybrids slightly later than in domestic cattle. $B_{1}$ males, like $F_{1}$ males, are sterile. The increased percentage of cattle blood in subsequent generations of hybrids results in considerable resemblance to cattle in respect of both the exterior appearance and the physiological properties of the animals.

\section{INTRODUCTION}

The series of experiments on cross-breeding of European bison with domestic cattle of the lowland black and white breed, which was initiated in 1961 was continued until 1966 ( $\mathrm{K} \mathrm{r}$ a sińs ka, 1967). Experiments were continued in the direction of backcross generations, mating $F_{1}$ or $B_{1}$ cows with a black and white bull. Sterility in males of the first and second generation (backcross) makes it impossible for hybrids reciprocally to crossbreed. Up to the end of $197011 \mathrm{~F}_{1}$ hybrids, 25 individuals of the $3 / 4$ cattle generation $\left(B_{1}\right)$ and 9 individuals of $7 / 8$ cattle generation $\left(\mathrm{B}_{2}\right)$ were obtained in the experiment at Białowieża. From 1966-1970 studies were continued on the development of hybrids, inheritance of morphological and physiological characters and fecundity. In addition 
from 1968-69 morphological analysis of internal organs, slaughter analysis and assessment of the value of the hybrids' hides (B r a e $\mathrm{nd}$ et al., 1969; Krasińska, 1969; Buchalczyk et al., 1971; Fedyk \& Krasińska, 1971; Pytel \& Krasińska, 1971; Szulc et al., 1971) was also carried out. The present report is the sixth to appear ${ }^{1}$ ) and presents the progress made in breeding studies from the beginning of 1966 to the end of 1970 .

\section{II. $\mathrm{F}_{1}$ HYBRIDS}

In 1966 there were 11 adult hybrids of the first generation (5 males and 6 females) in the experiment reserve, obtained from mating European bison with Polish red and lowland black and white cattle. From 1968 - 69 seven of the hybrids of this generation were allocated for slaughter and further analysis (Table 1).

At the end of $19682 \mathrm{~F}_{1}$ cows died of rabies, a rabies epizooty being observed in the Białowieża Primeval Forest during this period. It was chiefly wild predators which caught the disease - red foxes and Nyctereutes procyonoides - but cases were also found of rabid red and roe deer. A rabid fox or racoon dog must most likely have got through the fencing of the experimental reserve and bitten the two quietest $F_{1}$ cows in the hybrid herd - Fanny " and "Famela «. "Fanny " was the first to become ill. A lack of appetite was first observed, then the same day marked sialorrhoea. The cow, which normally had been very quiet and mild, became aggressive and attacked other animals. Its voice changed considerably, and it lowed hoarsely. After a day and half of the disease it ceased to low and when given water bit the bucket, while it let fall beet and hay from its mouth. It died on the third day of the disease. A second cow, "Famela ", became ill four days later and its illness took a mild form of rabies. It went right off its food, produced large quantities of saliva and remained completely indifferent to its surroundings. It died on the fourth day of the disease. Negri's bodies were found to be present when the brains of the two cows were examined. The fact of occurrence of rabies in hybrids is interesting, especially in view of the fact that no European bison have been observed to fall victims to this disease.

$F_{1}$ hybrids exhibit a build intermediate between the parent forms, domination of European bison characters being observed in the structure of horns in females, the hump in males, and stronger development of the fore part than the hind part of the body in hybrids of both sexes ( $\mathrm{K} \mathrm{r}$ asińs k a, 1969).

1) Cf. earlier results of these studies contained in the following studies: De h n e l, 1960, 1961; Demiaszkiewicz, 1961; K r as ińska, 1963, 1967. 
Table 1

List of hybrids of European bison and domestic cattle.

\begin{tabular}{|c|c|c|c|c|c|c|c|c|c|}
\hline \multirow{2}{*}{ No. } & \multirow{2}{*}{ Name \& sex } & \multicolumn{2}{|c|}{ Parents } & \multirow{2}{*}{\multicolumn{3}{|c|}{ Born }} & \multirow{2}{*}{\multicolumn{3}{|c|}{ Died }} \\
\hline & & Father & Mother & & & & & & \\
\hline \multicolumn{10}{|c|}{ Wilon } \\
\hline 1 & Filon, Mi & $p r$ & $w$ & 6 & VIII & 1960 & 11 & VI & $1968 *$ \\
\hline 2 & Filip, M & $p r$ & $w$ & 25 & VIII & 1960 & 20 & $\mathrm{X}$ & $1969 *$ \\
\hline 3 & Fama. F & $w$ & $p r$ & 14 & $\mathrm{X}$ & 1960 & 8 & $\mathrm{X}$ & $1968^{*}$ \\
\hline 4 & Filutka, F & $p r$ & $w$ & 7 & IX & 1961 & 4 & $\mathrm{XII}$ & 1968 \\
\hline 5 & Famela, F & $w$ & $p r$ & 30 & II & 1962 & & & \\
\hline 6 & Facet, $\mathrm{M}$ & $w$ & $b w$ & 28 & IV & 1962 & 24 & IX & $1968^{*}$ \\
\hline 7 & Farad, M & $w$ & $b w$ & 29 & IV & 1962 & 29 & $\mathrm{XI}$ & 1968 \\
\hline 8 & Fanny, F & $w$ & $b w$ & 30 & IX & 1962 & 4 & $\mathrm{XI}$ & $1968^{*}$ \\
\hline 9 & Fakir, M & $w$ & $b w$ & 12 & VIII & 1963 & & & \\
\hline 10 & Figa, F & bw & $w$ & 23 & VIII & 1963 & 4 & $\mathrm{X}$ & $1968^{*}$ \\
\hline 11 & Fatima, F & $w$ & $b w$ & 29 & VIII & 1964 & & & \\
\hline \multicolumn{10}{|c|}{ Foniv M } \\
\hline 2 & $\begin{array}{l}\text { Fenix, M } \\
\text { Feta, F }\end{array}$ & bw & Filutka & 9 & $\mathrm{~V}$ & $\begin{array}{l}1903 \\
1963\end{array}$ & $\begin{array}{r}4 \\
24\end{array}$ & VIII & 1966 \\
\hline 3 & Fez, M & bw & Filutka & 18 & V & 1964 & 23 & IX & $1968^{*}$ \\
\hline 4 & Fetysz, M & bw & Fama & 28 & V & 1964 & 7 & $\mathrm{X}$ & $1969^{*}$ \\
\hline 5 & Fen, M & bw & Fama & 14 & IV & 1965 & 25 & $\mathrm{XI}$ & $1968^{*}$ \\
\hline 6 & Feb, M & $b w$ & Filutka & 26 & IV & 1965 & 25 & $\mathrm{XI}$ & $1968^{*}$ \\
\hline 7 & Femiana, F & bw & Fanny & 2 & V & 1965 & & & \\
\hline 8 & Fey, M & jersey & Famela & 16 & IX & 1965 & 20 & $\mathrm{X}$ & $1969^{*}$ \\
\hline 9 & Fera, F & $b w$ & Figa & 14 & IV & 1966 & & & \\
\hline 10 & Feg, M & $b w$ & Filutka & 27 & IV & 1966 & 28 & IX & $1969^{*}$ \\
\hline 11 & Fama, F & bw & Fama & 17 & V & 1966 & 26 & VIII & 1968 \\
\hline 12 & Feld, M & $b w$ & Fama & 7 & IV & 1967 & 26 & $\mathrm{XI}$ & $1968^{*}$ \\
\hline 13 & Festyn, M & bw & Figa & 25 & IV & 1967 & 8 & IX & $1969^{*}$ \\
\hline 14 & Fewa, F & bw & Filutka & 11 & V & 1967 & & & \\
\hline 15 & Fern, M & bw & Fatima & 2 & VIII & 1967 & 8 & VIII & 1967 \\
\hline 16 & Fenny, F & bw & Fanny & 29 & VIII & 1967 & & & \\
\hline 17 & Fellach, M & $b w$ & Famela & 12 & IX & 1967 & 8 & IX & $1969^{*}$ \\
\hline 18 & Ferma, F & $b w$ & Fama & 16 & IV & 1968 & 28 & IX & $1969^{*}$ \\
\hline 19. & Feska, F & $b w$ & Figa & 2 & V & 1968 & & & \\
\hline 20 & Felpa, F & bu & Fatima & 1 & VI & 1968 & & & \\
\hline 21 & Fell, M & bw & Fanny & 28 & VI & 1968 & & & \\
\hline 22 & Felly, F & $b w$ & Famela & 21 & VII & 1968 & 22 & $\mathrm{X}$ & $1969 *$ \\
\hline 23 & Fest, M & $b w$ & Figa & 11 & IV & 1969 & 22 & $\mathrm{X}$ & 1969* \\
\hline 24 & Felon, M & $b w$ & Fama & 22 & IV & 1969 & 20 & $\mathrm{X}$ & $1969 *$ \\
\hline 25 & Festynka, F & $b w$ & Figa & 14 & IV & 1970 & & & \\
\hline & & & $\mathrm{B}_{2}$ & & & & & & \\
\hline 1 & Fela, F & $b w$ & Femina & 18 & IV & 1967 & 22 & $\mathrm{X}$ & $1969 *$ \\
\hline 2 & Fega, F & bu, & Fema & 21 & VI & 1968 & & & \\
\hline 3 & Ferajna, F & $b w$ & Fera & 15 & VIII & 1968 & & & \\
\hline 4 & Fenicja, F & $b w$ & Femina & 2 & V & 1969 & & & \\
\hline 5 & Fed, M & $b w$ & Fewa & 12 & III & 1970 & 12 & III & 1970 \\
\hline 6 & Ferrara, F & $b w$ & Fera & 19 & III & 1970 & & & \\
\hline 7 & Festa, F & $b w$ & Feska & 31 & V & 1970 & & & \\
\hline 8 & Fenig, M & $b w$ & Felpa & 8 & IX & 1970 & & & \\
\hline 9 & Febra, F & $b w$ & Fenny & 11 & IX & 1970 & Sti & llborn & \\
\hline
\end{tabular}

Abbreviations: $w$ - wisent (European bison); $p r$ - Polish red cattle; bw - black white lowland cattle; * slaughtered.

These hybrids inherit the temperament of their wild forebears. Even those animals which were mild during the first years of life (»Facet ) 
became aggressive with age. They are extremely strong. The bulls are victorious in fights with the male European bison. Like European bison, bull hybrids readily break young trees, raise windfallen trees and trample down wooden fences wherever they find weak places in them. An old male when irritated by, for instance, the presence of another bull, paws the ground with its forelegs, throws earth over its back,
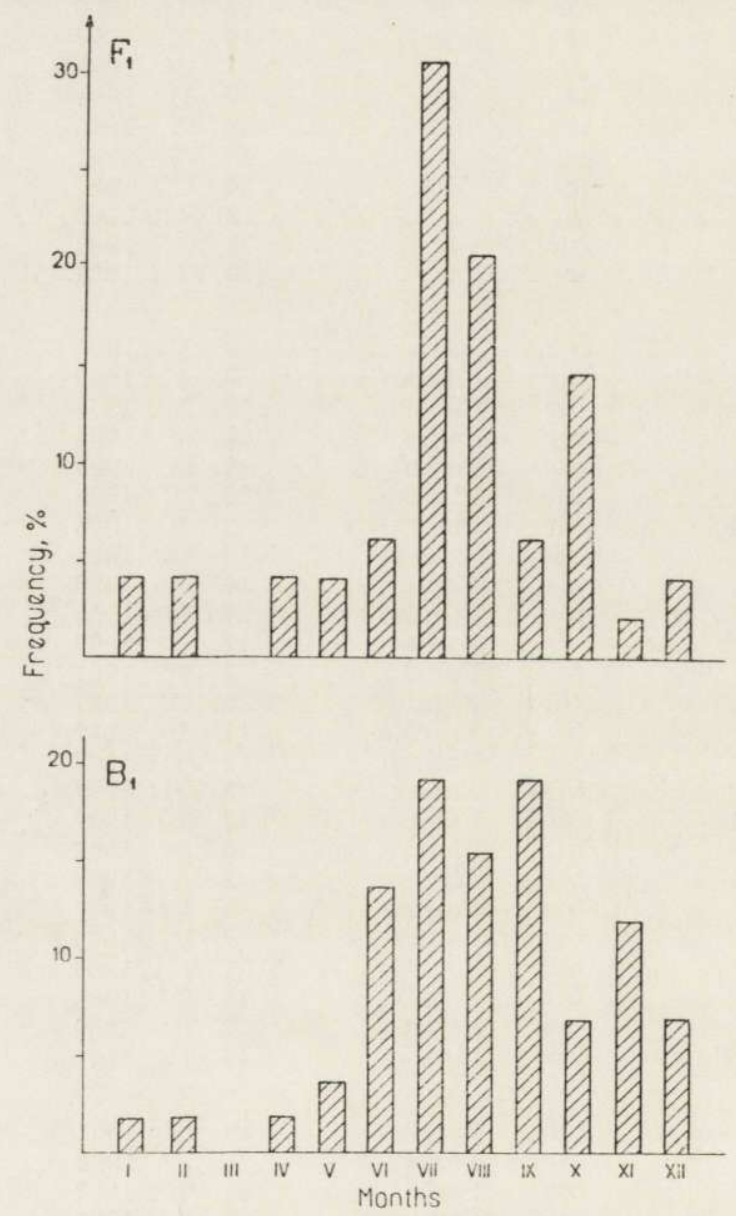

Fig. 1. Distribution of oestrus manifestations in females of $F_{1}$ and $B_{1}$ generations during a yearly cycle.

lowers its head and bellows. In summer when there are large numbers of insects the hybrids, like European bison, take sand baths.

The noise made by hybrids differs from that of the European bison and is more similar to that of cattle.

They readily supplement the fodder they receive with bark, young shoots and leaves of trees and bushes. 
The spring moult lasts with hybrids from February to May. As the hybrids of this generation have long, sharp horns mechanical injuries - are frequently observed among them. For instance the cow "Filutka" in July 1967 had an extensive wound in the inguinal region, measuring $20-25 \mathrm{~cm}$, but this healed without medical attention (as the cow could not be caught) within a short time without leaving any trace.

\section{1. $\mathbf{F}_{1}$ Cows}

From 1966-68 there were $6 \mathrm{~F}_{1}$ cows in the Białowieża reserve, two of which had been obtained from mating a female European bison with a domestic bull (Table 1). Three cows were allocated for slaughter and only one - Figa" — was left for further breeding. After these cows had attained sexual maturity they produced young every year from mating with a domestic bull, 17 calves being born during this period In all from the start of the experiment until $1970 \mathrm{~F}_{1}$ cows produced $25 \mathrm{~B}_{1}$ calves $(3 / 4$ cattle) and one abortion was found to occur in the 7 th month of gestation. All the cows assiduously cared for their young.

In cows of this generation the oestrus occurred most frequently $(51 \%$ of all cases) in July and August, i.e. similarly as it was observed earlier (cf. Krasińska, 1967). The mating period began in June and sometimes continued up to October (Fig. 1). It was only in the case of $\gg \mathrm{Fa}$ mela " that oestrus was observed at different times of the year. No effective coverings by bulls (apart from "Famela «) were observed outside the rutting period. Oestrus sporadically observed in winter occurred only in cows which had not been mated with a bull in summer. During the mating season the intervals between oestrus were $20-21$ days, and if the cows were not covered during this period, oestrus appeared again after an interval of several months.

Symptoms of gestation are less clearly marked in $\mathrm{F}_{1}$ cows than in domestic cows. From 10-14 days before the birth of the calf the vulva is swollen and the udders increase in size. Length of gestation is on an average $275.6 \pm 4.57$ days, and is therefore intermediate between lengths of gestation in the initial forms (Table 2). Calving takes place without complications, and the placentas were discharged normally. Post partum oestrus occurred on an average after $68.1 \pm 24.14$ days $(\mathrm{N}=22)$. The majority of the cows became pregnant during the post partum oestrus. The influence of the European bison clearly dominates in the characters of reproduction by $F_{1}$ cows.

\section{F $_{1}$ Bulls}

There were 5 adult $F_{1}$ bulls in the Białowieża experimental reserve from 1966. From 1968-69 three of these were allocated for slaughter 
(Table 1), "Filon « and »Facet « being left for further breeding. As in the first years of the experiment ( $\mathrm{Krasińska,1967)} \mathrm{bulls} \mathrm{mating} \mathrm{natu-}$ rally with domestic cows or $\mathrm{F}_{1}$ cows failed to sire young. Histological examination of the testes, revealed inhibition of spermatogenesis at the level of spermatogonia or primary spermatocytes ( $\mathrm{F}$ e d y k \& K r a s ińsk a, 1971). These bulls have, however, well-formed sexual drive. They

Table 2

Characteristics of breeding of $F_{1}$ females.

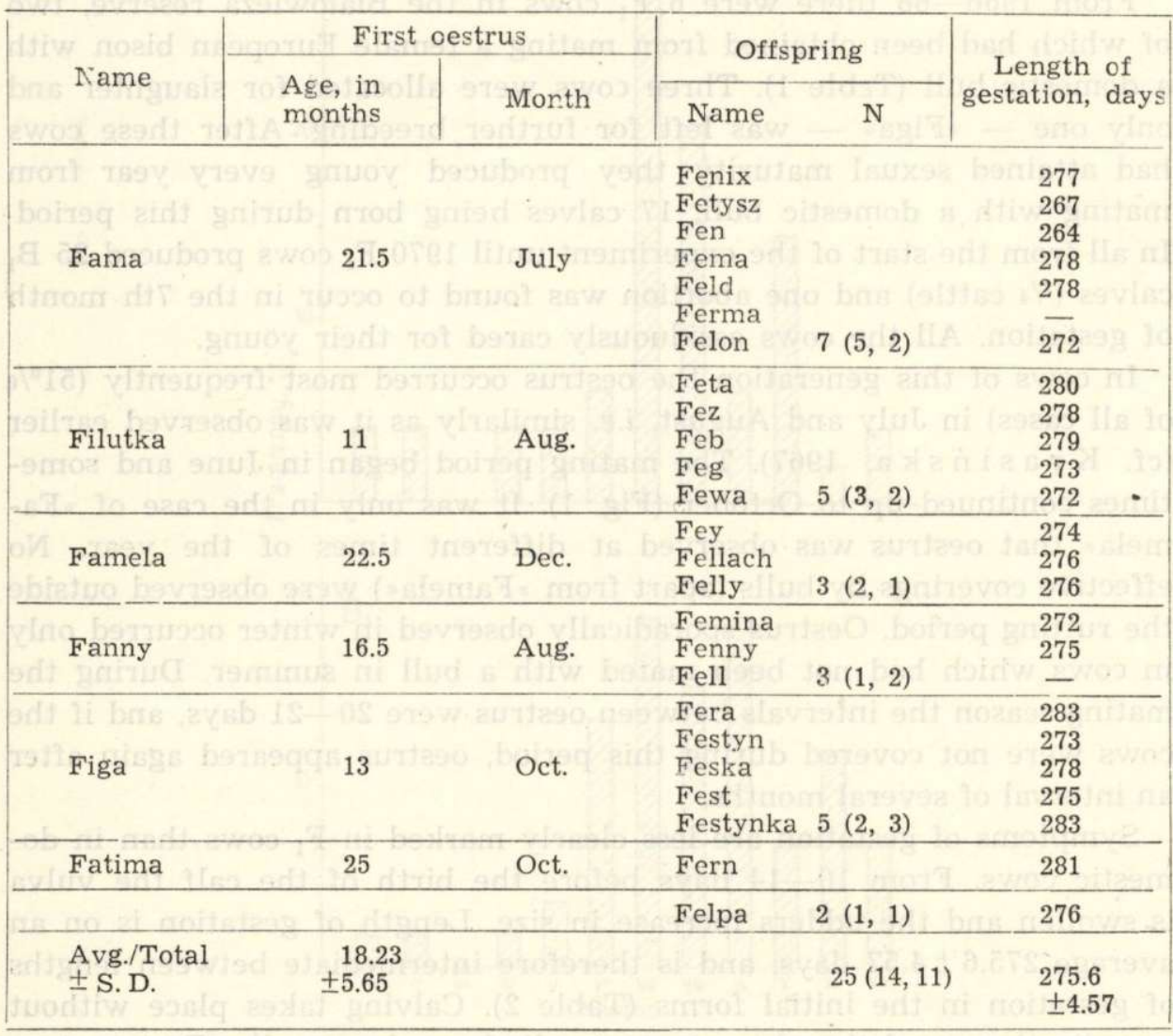

fight over cows and break down fences in order to get into other enclosures where there are cows in oestrus. They are strong and domestic bulls always lose in fights with them.

\section{III. $B_{1}$ HYBRIDS (3/4 DOMESTIC CATTLE GENERATION)}

From 1966-1970 17 hybrids of this generation were born at Białowieża. In all from the start of the experiment 25 individuals $(14,11)$ were 
obtained. Fifteen hybrids were allocated for slaughter (Table 1). During this time two of the hybrids died ( Feta «, "Fern«) and there was one abortion during the 7 th month of gestation. The cause of death of the adult cow "Feta " was acute insufficiency of the digestive system, while "Fern" died on the 6th day of life as the result of a mechanical injury in the head.

Hybrids of this generation are of a build intermediate between the parent forms ( $F_{1}$ and lowland black and white cattle) but are more similar to cattle than individuals of generation $F_{1}$. Only the forepart of the body exhibits characters (although to a slight degree only) of the European bison. The hump does not occur in males. The coat in hybrids is smooth, and there is no bison beard. Colouring varies greatly, despite the fact that the sire of all the hybrids was a black and white bull. Individuals are encountered with a red coat with white marking or a brown coat (7 cases) inherited from grandsires of the Polish red breed. The remainder are black with white markings (13 individuals) or black and white (5 animals).

These hybrids are milder than the first generation, but very aggressive individuals are also encountered ("Fenix ", "Femina «), in addition to the quiet ones (»Fellach", "Fenny«). They resort to supplementary natural food to a lesser degree than $F_{1}$ hybrids, but like them spend the winter in enclosures without any barns. Mechanical injuries heal quickly in these animals also. In the case of the cow $» F e n n y "$ a considerable hernia appeared on the underbelly following mechanical injury during the last phase of gestation. The calf was in fact stillborn, but the hernia disappeared without trace.

\section{B B $_{1}$ ows}

During the period referred to there were $11 \mathrm{~B}_{1}$ cows in the reserve, 2 of which were allocated for slaughter (Table 1) and one died. These cows mature sexually slightly later than domestic heifers, that is, beginning with the eleventh month of life. The first oestrus appeared at the age of $13.2 \pm 1.98$ months. In the majority of cases the first oestrus occurred during the period from June to September (Table 3). In this generation, however, the seasonal character of reproduction observed in generation $F_{1}$ disappears. Successive oestruses occur throughout the whole year, but intensify during the period from May - December (Fig. 1), although a large percentage of effective-matings occurred in summer and early autumn.

Considerable individual fluctuations in length of gestation occur, the average being $277.2 \pm 5.85$ days (Table 3 ), approaching that typical of cattle (277-290 after A s d e 1l, 1964). 
Only 8 of the 9 sexually mature cows produced young. These cows also failed to calve as regularly every year as first generation cows, "Fewa « for instance producing weak calves which died immediately after birth and which she completely neglected. The $B_{1}$ cow $» F$ eta $"$ did not become pregnant throughout the whole period of its stay in the reserve, and when dissected was found to have a tumour on an ovary. Similar limited fecundity in female $3 / 4$ European bison hybrids was observed in the Askania Nova reserve (cf. Z a b l o ck i j, 1939). Post partum oestrus occurred in $B_{1}$ cows $53.3 \pm 23.44$ days after giving birth.

Table 3

Characteristics of breeding of $B_{1}$ females.

\begin{tabular}{|c|c|c|c|c|c|}
\hline \multirow{3}{*}{ Name } & \multicolumn{2}{|c|}{ First oestrus } & \multicolumn{2}{|c|}{ Offspring } & \multirow{3}{*}{$\begin{array}{l}\text { Length of } \\
\text { gestation, days }\end{array}$} \\
\hline & \multirow{2}{*}{$\begin{array}{l}\text { Age, in } \\
\text { months }\end{array}$} & \multirow{2}{*}{ Month } & & & \\
\hline & & & Name & $\mathrm{N}$ & \\
\hline Fewa & 14 & July & Fed & $1(1,0)$ & 272 \\
\hline Fera & 17 & Sept. & $\begin{array}{l}\text { Ferajna } \\
\text { Ferrara }\end{array}$ & $2(0,2)$ & 281 \\
\hline Femina & 14 & July & $\begin{array}{l}\text { Fela } \\
\text { Fenicja }\end{array}$ & $2(0,2)$ & $\begin{array}{l}275 \\
288\end{array}$ \\
\hline Feska & 13 & June & Festa & $1(0,1)$ & 281 \\
\hline Felpa & 12 & June & Fenig & $1(1,0)$ & 274 \\
\hline Fenny & 11 & July & Febra & $1(0,1)$ & 277 \\
\hline Fema & 14 & June & Fega & $1(0,1)$ & 270 \\
\hline Feta & 11 & April & - & - & - \\
\hline $\begin{array}{l}\text { Avg./Total } \\
\pm \text { S. D. }\end{array}$ & $\begin{array}{c}13.2 \\
\pm 1.98\end{array}$ & & & $9(2,7)$ & $\begin{array}{l}277.2 \\
\pm 5.85\end{array}$ \\
\hline
\end{tabular}

Cows of this generation mated with a bw bull produced $9 \mathrm{~B}_{2}$ calves ( $7 / 8$ cattle) up to the end of 1970 , with sex ratio of $2: 7$ (Table 3 ). Two died. These calves do not differ in appearance from domestic cattle and are readily tamed.

\section{2. $\mathbf{B}_{2}$ Bulls}

Of the 14 bulls of this generation 13 were allocated for slaughter and analysis, leaving only "Fell " for further breeding (Table 1). $\mathrm{B}_{1}$ bulls begin to cover cows in the 11th month of life, but on an average at the age of $13.3 \pm 2.64$ months, that is, slightly later than domestic bulls (cf. e.g. B i e la ński, 1962). Like the $\mathrm{F}_{1}$ bulls, these also sired no progeny. All natural matings proved ineffective. Histological examination of the testes revealed in three bulls only the presence of a small number of 
spermatozoa in the seminal ducts. The efferent ducts of the epidydymis were, however, empty in these individuals. In the remaining $\mathrm{B}_{1}$ bulls inhibition of spermatogenesis was observed at the level of primary or secondary spermatocytes (F e dyk \& Krasińska, 1971).

$B_{1}$ bulls are inferior to generation $F_{1}$ bulls in dimensions and strength, and are also less aggressive towards humans.

Increase in the percentage of cattle blood in hybrids of European bison and domestic cattle causes the animals to be increasingly similar to domestic cattle in respect of both external appearance and physiological properties.

\section{REFERENCES}

1. A sdell S. A., 1964: Patterns of mammalian reproduction. Comstoc Publ. 1-437. Ithaca, New York.

2. Bielański W., 1962: Rozród zwierząt gospodarskich. Państw. Wyd. Roln. i Leśn. 1-545. Warszawa.

3. Braend M., Gasparski J. \& Krasińska M., 1967: Variation of hemoglobin in cattle bison crosses. Hereditas 62: 185-192.

4. Buchalczyk A., Krasińska M. \& Wolk E., 1971: Morphological blood indices in hybrids of European bison and domestic cattle. Acta theriol., 16, 28: 439-447.

5. Dehnel A., 1960: Beobachtungen über Zusammenleben von Wisent und Hausrind. Acta theriol., 3, 14: 314-317.

6. Dehnel A., 1961: Die ersten Hybriden zwischen Bos taurus dom. L. of und Bison bonasus (L.) ๆ. Acta theriol., 5, 3: 45-50.

7. Demiaszkiewicz W., 1961: Die Geburt eines Hybriden von Bison bonasus (L.) o und Bos taurus dom. L. ㅇ. Acta theriol., 5, 4: 51-56.

8. Fedyk S. \& Krasińska M., 1971: Studies on the spermatogenesis of domestic cattle and European bison hybrids. Acta theriol., 16, 29: 449-464.

9. Krasińska M., 1963: Weitere Untersuchungen über Kreuzungen des Wisentes, Bison bonasus (Linnaeus, 1758) mit dem Hausrind Bos taurus dom. Lin n a u s, 1758. Acta theriol., 7, 14: 301-310.

10. Krasińs k a M., 1967: Crosses of wisent and domestic cattle. V. Acta theriol., 12, 5: $67-80$.

11. Krasińska M., 1969: The postnatal development of $F_{1}$ hybrids of European bison and domestic cattle. Acta theriol., 14, 7: 69-117.

12. Pytel S. \& Krasińska M., 1971: Morphology of the stomach and intestines in hybrids of European bison and domestic cattle. Acta theriol., 16, 31: 471-481.

13. Szulc M., Tropiło J. \& Krasińska M., 1971: Dressing percentage and utility value of the meat of European bison and domestic cattle hybrids. Acta theriol., 16, 32: 483-504.

14. Z a blockij M. A., 1939: Tridcat' pjat' let razvedenia zubrov i ih gibridov v Zooparke Askania Nova (1902-1937). [In „Kavkazskij zubr«] Glav. Upravl. po Zoopark. Zoosad.: 73-137. Moskva.

Accepted, September 5, 1971.

Mammals Research Institute,

Polish Academy of Sciences, Białowieża. 


\section{Malgorzata KRASIŃSKA}

HYBRYDYZACJA ŻUBROW Z BYDŁEM DOMOWYM. VI

\section{Streszczenie}

Przedstawiono wyniki hodowlane doświadczenia nad krzyżowaniem żubrów $\mathrm{z}$ bydłem domowym w latach 1966-1970. W okresie tym urodziło się 17 mieszańców pokolenia $\mathrm{B}_{1}\left(3 / 4\right.$ domowe) oraz 9 sztuk $\mathrm{B}_{2}(7 / 8$ domowe). Łącznie od początku eksperymentu uzyskano 11 sztuk pokolenia $F_{1}, 25$ pokolenia $B_{1}$ oraz $9-B_{2}$. W latach 1968-69 przeznaczono na ubój 22 mieszańce różnych pokoleń w celu wykonania analiz morfologicznych, fizjologicznych oraz oceny wartości użytkowej mieszańców (Tabela 1). Stan mieszańców na koniec 1970 roku w rezerwacie doświadczalnym wynosił 3 sztuki pokolenia $F_{1}, 8$ sztuk pokolenia $B_{1}$ i $6-B_{2}$.

Długość ciąży u krów $F_{1}$ wynosiła średnio $275,6 \pm 4,57$ dni, natomiast u $B_{1}$ $277,2 \pm 5,85$ dni zbliżając się do typowej dla bydla (Tabela 2,3 ).

W odróżnieniu od pokolenia $F_{1}$ nie wszystkie krawy $B_{1}$ dawały potomstwo lub nie było ono w pełni wartościowe. Porody nie następowały regularnie co roku jak w pokoleniu $F_{1}$.

Pierwsze ruje u krów pokolenia $B_{1}$ występują w wieku średnio $13,2 \pm 1,98$ miesiąca, a więc nieznacznie później niż u jałówek domowych. Ruje w odróżnieniu od pierwszego pokolenia występowały w różnych porach roku (Ryc. 1). W pokoleniu ze zwiększonym procentem krwi bydła zanika sezonowość rozrodu obserwowana w pierwszym pokoleniu mieszańców (Ryc. 1, 2).

Samce $B_{1}$ zaczynają kryć krowy w wieku 11 miesięcy, średnio $13,3 \pm 2,64$ miesięca, są jednak podobnie jak $F_{1}$ bezpłodne. 